\title{
MYSTICAL LIFE AND SOCIAL WORK IN CONTEMPORARY MONASTIC LIFE. TWO CASE STUDIES: MOTHER MARIA SKOBTSOVA AND MOTHER GAVRILIA PAPAIANNIS
}

Benedict Vesa*

\begin{abstract}
In the oriental monastic spiritual tradition there was occasionally a difficult rapport between contemplative life and social work. Throughout history, there have been examples that have brought nuances to this perspective. Mother Maria Skobtsova and Mother Gavrilia Papaiannis stand firmly to support the idea of a relation of the "mother-daughter" type between mystical life and social activity, interpreted as two obligatory forms and stages of the same spiritual itinerary. Both nuns belonged to the category of city monastics, focused on the social philanthropic service. Their orthopraxis have also proved to be the source of an ecumenical attitude, while serving in their confessional Church. In this paper I will concretely attempt to picture a possible rapport between mystical life and social work, by looking at the spiritual itinerary of the two above-mentioned religious representatives within the frame of the Orthodox tradition, in general, and within the contemporary religious landscape, in particular.
\end{abstract}

Keywords: monastic life, mystical life, social service, orthopraxis, Maria Skobtsova, Gavrilia Papaiannis

In the spiritual tradition and, in particular, in the Oriental Christian monastic life, there was a difficult rapport between mystical contemplative life and social work, being not always visible, but at least envisaged as a permanent primate of the former over the latter. One may find opinions according to which, for a

*Hierom. Assist. lect. PhD “Babeş-Bolyai” University, Cluj-Napoca, Romania. 
monachos, social service is not an obligatory task, but rather a philanthropic permanent mediation, expressed in the prayer and mourning for the entire humankind. This kind of perception has brought some accusation regarding an implied non-action of monastics, while promoting a flee from the "world" with its problems (social, political, or religious). Throughout history, there were examples which, if not contradicting this opinion, at least brought nuances and showed the existence of different perspectives. Mother Maria Skobtsova and Mother Gavrilia Papaiannis stand firm to support the idea of a good relation between inner mystical life and social service. Both of them belonged to the category of city monastics, not really circumscribed to a monastery, but more identified with their social philanthropic service. Their orthopraxis also proved to be the source for an ecumenical attitude, while serving in their confessional Church.

In this paper I will concretely try to picture a possible rapport between mystical life and social work, by looking at the spiritual itinerary of the two above-mentioned religious representatives within the frame of the Orthodox tradition, in general, and within the contemporary religious landscape, in particular. This study aims to be contextual and practical. Therefore I will mostly use the inductive method.

\section{Mother Maria Skobtsova and the monasticism in the world}

Ecclesial life cannot be interpreted reductively as an acquisition of personal perfection and inner hesychia, but one is called to go out to serve those in need, and this implies a permanent inner struggle and outer activity. The Church is not a kind of aesthetic perfection and, consequently, we cannot restrain our work to aesthetic swooning. Mother Maria Skobtsova, according to the message of her life, proposes the second path expressed above - the restless "liturgy of the brother", in shifting and uncertain times. She used to admonish those seeking "the 
rest" and "the peace" of a contemplative life:

Go to church, because there you will feel real anguish for your sins, for your perdition, for the world's sins and perdition. There you will feel an unappeasable hunger for Christ's truth. There, instead of becoming lukewarm, you will be set on fire; instead of pacified, you will become alarmed; instead of learning the wisdom of this world, you will become fools for Christ ${ }^{1}$.

Mother Maria, as she is known, Elizabeta Pilenko by birth, has become in recent years an example of contemporary Orthodox social service. Her most representative work was during the Nazi occupation of Paris in World War II, when she used to offer assistance to French Jewish people, which led to her arrest and deportation to the Ravensbrück concentration camp ${ }^{2}$. She was born in 1891, in Riga, then part of the Russian Empire. Her father, Yuri, ober-procurator, came from a noble Crimean Cossack family, and her mother, Sophia de Launay, was descended from the last Bastille governor who was killed during the French Revolution. She was endowed with the gift of poetry and painting, and was among the first women who studied Theology at the Academy in St. Petersburg.

Her early marriage ended in divorce, followed by another one with the same ending, with the officer Daniel Skobtsov. She lost all her three children from these two marriages at an early age: Nastia, at the age of infancy, because of meningitis, Gaiana, as an adult, back in Russia, and Iura, in a premature death, packed off to a Nazi camp. After a long travel through Georgia, Turkey,

\footnotetext{
${ }^{1}$ Maria Skobtsova,Under the signs of our times, in "Mother Maria Skobtsova: Essential Writings", Maryknoll NY, Orbis 2003, p. 113.

${ }^{2}$ Probably the most well-known source of her life is the biography written by Sergei Hackel - "Pearl of Great Price: the Life of Mother Maria Skobtsova", Crestwood, NY, St. Vladimir's Seminary Press, 1981, translated into many languages since its first edition in 1965. She was canonized by the Eastern Orthodox Church in 2004. Her day festival is July 20.
} 
and Serbia, the final journey ended in Paris, where she became an active member of the Russian immigrants' group, assisting those in distress and poverty.

Once divorced by her husband, Daniel, Liza received, in 1923, the monastic tonsure. On this occasion, Archbishop Eulogy Georgievsky said: "Your name is Maria, in memory of St. Mary of Egypt. If, after a scandalous life, she retired to the desert, so you go, talking and working in the desert the hearts of people!"3. Both of them knew it was about a new type of monasticism, engaged in the world, and marked by the complete absence of even "the subtlest barrier which might separate the heart from the world and its wounds". She used to call it "monasticism in the world".

Very soon she founded a house of hospitality, where 25 persons in need could enjoy a hot meal, shelter, and a friendly counselor. Two years later a new location was founded - a derelict house of three storeys in Rue de Lourmel, an area where many impoverished Russian refugees had settled. Here she could feed one hundred persons. The house had the additional advantage of having stables in the back, which were transformed into a small church.

The theological framework of Maria's social vision is well expressed in two basic essays, published in 1930: "The Second Gospel Commandment" and "The Mysticism of Human Communion". In both articles, the starting point is Matthew 22: 37-39: "Love the Lord your God with all your heart and with all your soul and with all your mind" and "Love your neighbor as you love yourself". She used to call them the "bi-une

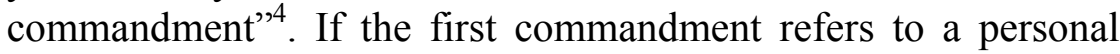

\footnotetext{
${ }^{3}$ Hélène Arjakovsky-Klépinine, Bucuria dăruirii - o biografie spirituală, in "Iubirea nebună de aproapele. Viața şi invățăturile Maicii Maria Skobțova", Sibiu, Deisis, 2008, p. 49.

${ }^{4}$ Maria Skobtsova, The Second Gospel Commandment, in "Mother Maria Skobtsova: Essential Writings", p. 47.
} 
struggle and indicates one personal responsibility, the second calls for communitarian responsibility and provides the foundation for Christian collective life ${ }^{5}$.

\section{The love of God and love of one's neighbour form a single}

truth and, finally, represent the entire law:

Christ gave us two commandments: to love God, and to love our fellow man. Everything else, even the commandments contained in the Beatitudes, is merely an elaboration of these two commandments, which contain within themselves the totality of Christ's Good News. Furthermore, Christ's earthly life is nothing other than the revelation of the mystery of love of God and love of the neighbour. These are, in sum, not only the true, but the only measure of all things. And it is remarkable that their truth is found only in the way they are linked together. Love for man alone ${ }^{6}$ leads us into the blind alley of an anti-Christian humanism, out of which the only exit is, at times, the rejection of the individual human being and of the love toward him, in the name of all mankind. Love for God without love for man, however, is condemned:

${ }^{5}$ Natalia Ermolaev argues that Mother Maria's social vision contributes to the panorama of the Russian theologians who advocated for a more social involvement, next to Alexei Khomiakov (with the ides of "sobornost", conciliarity and collectivity), Vladimir Solovyov (the doctrine of "Bogochelovechestvo", Godmanhood), Fyodor Dostoevsky (the collective responsibility). She writes: "It is our duty to bring these theoretical ideas and philosophical systems, the ideas of sobornost and Godmanhood... into practical use - for our personal spiritual routes, for the innermost and inward lives, as well as for our external endeavours" (The Second Gospel Commandment, pp. 59-60). For details see The Marian Dimension of Maria's Orthodox Social Christianity, in "Philantropy and Social Compassion in Eastern Orthodox Tradition: Papers of the Sophia Institute Academic Conference, New York, 2009”, 2010, pp. 182-199 (here 184).

6 While admiring the efforts of the Catholic "Rerum Novarum" and the Protestant Social involvement, she argues that both systems, based on a "rationalistic humanism", disregard the mystical and eschatological foundation of social Christianity that interprets life as an itinerary towards deification. The social service must transfigure the world. The concept she develops is called "mysticism of human communion" (The Mysticism of Human Communion, in "Mother Maria Skobtsova: Essential Writings", pp. 75-76). 
You hypocrite, how can you love God whom you have not seen, if you hate your brother whom you have seen (1 John 4:20). Their linkage is not simply a combination of two great truths taken from two spiritual worlds. Their linkage is the union of the two parts of a single whole?

The second important theological argument is Christological and anthropological at the same time: the imitation of Christ's service of those in need, and the identification of Christ in each person that stands before us. Her spirituality was based on the Incarnation of Christ, as a sign of God's love towards people, closely followed by the invitation to achieve His likeness. By accepting this invitation, one contributes to the Christification of the world ${ }^{8}$, that is, the introduction of all creation in Christ. The thread of this reasoning is the Virgin, who achieved this resemblance in the highest form. Consequently, just as in her case, our souls may conceive Christ in them, in His image and perception in the others:

If a person is not only the image of God, but also the image of the Mother of God, then that person should also be able to see the image of God and the image of the Mother of God in every other person. In our God-maternal soul, not only is the birth of the Son of God announced and Christ born, but there also develops the keen perception of Christ's image in other souls. And in this sense, the God-maternal part of the human soul begins to see other people as its children; it adopts them for itself... insofar as we must strive to follow her path, and as her image is the image of our human soul, so we must also perceive God and the Son in every person. God, because each person is the image and likeness of God; the Son, because as it gives birth to Christ within itself, the human soul thereby adopts the whole Body of Christ for itself, the whole of Godmanhood, and every person individually'.

${ }^{7}$ Maria Skobtsova, Types of Religious Lives, in "Mother Maria Skobtsova: Essential Writings", pp.173-174.

${ }^{8}$ Types of Religious Lives, pp. 181-184.

9 Maria Skobtsova, On Imitating the Mother of God, in „Mother Maria Skobtsova: Essential Writings", pp. 68-69. 
In each person one can identify the icon of God incarnated in the world and, consequently, one is invited to venerate the image of God in one's brothers or sisters. Based on this premise, she clearly expresses in her daily life what Saint John Chrysostom calls "the sacrament of the brother", or the ecumenical expression "the liturgy after the Liturgy".

Next to Christological and anthropological bases, she evokes the eschatological dimension of social service. The only criterion of the Last Judgment is the love of the brother. Quoting Matthew 25, she argues:

The way to God lies through love of people. At the Last Judgment I shall not be asked whether I was successful in my ascetic exercises, nor how many bows and prostrations I made. Instead, I shall be asked, Did I feed the hungry, clothe the naked, visit the sick and the prisoners? That is all I shall be asked. About every poor, hungry and imprisoned person, the Savior says: 'I was hungry and thirsty, I was sick and in prison.' To think that he puts an equal sign between himself and anyone in need. ... I always knew it, but now it has somehow penetrated to my sinews. It fills me with awe ${ }^{10}$.

And lastly, she also brings the Mariological pattern to describe her social vision. For her, the Virgin Mary is the model for the active and transformative love for the other, specifically when standing at the Cross. If Christ suffers the passion, His mother experiences the compassion. At Golgotha, Virgin Mary fully feels the pain of her Son, not "for", but "with". This compassion appears also at the lexical level, when using the prefix "co":

${ }^{10}$ Pravoslavnoe Delo (Orthodox Action), Paris, 1939, 30, quoted by Michael Plekon, The Sacrament of the Brother/Sister: The Lives and Thought of Mother Maria Skobtsova and Paul Evdokimov, in "Saint Vladimir Theological Quarterly", 49 (2005), 3, pp. 313- 334 (here 334). 
He endures voluntary suffering on the cross - she involuntarily cosuffers with Him. He bears the sins of the world - she collaborates with Him. She co-participates, she co-feels, co-experiences. His flesh is crucified - she is co-crucified ${ }^{11}$.

The passage from personal to communitarian is well expressed in the exegesis Mother Maria makes with reference to the place of the Virgin Mary in Christ's Economy, emphasizing its social perspective. As Christ offered His life for the world, so did Mary, following Him up to the end. She speaks about the twoedged sword $^{12}$. Enlarging this idea, she will highlight the fact that we can participate in the suffering of the other "by opening our own heart to the stroke of the double edged sword"13, the true measure of love. In the compassionate works, the entire community participates in the Son's self-sacrifice and the Mother's compassion. And this is called "churching of life", bringing a glimpse of love and light in the daily endeavor. Mother Mary uses the concept of a "liturgy outside the Church"14, that is, not simply philanthropy, but a mystical project that generates a "communitarian life"15.

All these principles were put into action in her social service. After the Lourmel community functioned for two years, she involved some other international agencies and volunteers in the project, and opened three more boarding houses, as well as kitchens, infirmaries and a nursing home. A country house in the suburb of Paris, Noisy-le-Grand, was transformed by the

${ }^{11}$ Maria Skobtsova, On the Imitation of the Mother of God, in "Mother Maria Skobtsova: Essential Writings", p. 68.

${ }^{12}$ Ibidem, p. 67.

${ }^{13}$ Ibidem, p. 72.

${ }^{14}$ Maria Skobtsova,The Mysticism of Human Communion, in "Mother Maria Skobtsova: Essential Writings", pp. 79-80.

15 For details see Natalia Ermolaev, The Marian Dimension of Maria's Orthodox Social Christianity, pp. 190-191. 
Orthodox Action into a sanatorium for patients suffering from tuberculosis.

Her service found its climax during the World War II. The Nazis occupied Paris in June 1940. Their arrival was the beginning of arrests of migrants, especially foreign Jewish people. Christian baptism proved to be a way out. The priest of the social house, Dimitri Klepinin, saved many Jewish from death this way. This did not remain hidden from the Nazis, and Father Dimitri, together with mother Maria, were arrested. Officer Hoffmann accused Mary's mother: "You have grown your daughter badly. She helps bastards!" Confirming the creed of her daughter' life, Sofia Pilenko answered: "She helps everyone. For a Christian like her, it is neither Jewish nor Greek. If you were in danger, she would have helped you too" ". Sent to the camp at Ravensbrück, she was gassed and cremated on Easter Eve 1945. One may infer here the ecumenical dimension of her social service, generated by an inner mystical perspective on the kenotic type, as professed by Jesus Himself.

The German poet Rainer Maria Rilke said: "Each one experiences the death he deserves". There are glorious and discrete deaths. The death of Mother Maria was a humble one, as that of the crucified Jesus whom she loved - "I did not love thee, death / I have loved what is living in this world: the eternity"17.

Her entire life was nothing but dedication, witnessing the "mystery of the brother" in the most authentic and exemplary manner. In a poetical way she proclaims her creed: "I want to know only the joy of offering. / To comfort the pain of the world with all my being! / The fire, the cry of the bloody dawn, / To mingle in the tears of compassion!" ${ }^{\prime 18}$.

\footnotetext{
${ }^{16}$ Hélène Arjakovsky-Klépinine, Bucuria dăruirii - o biografie spirituală, in "Iubirea nebună de aproapele", p. 81.

${ }^{17}$ Ibidem, p. 88.

${ }^{18}$ Să mângâi, in „Iubirea nebună de aproapele”, p. 302.
} 


\section{Mother Gavrilia Papaiannis and spiritual ecumenism}

The question Mother Gavrilia was often asked regarding the people of the "countries before Christ" was this: "Why do you consider the Indian or Muslim or Jewish people as being yours?" And she used to answer in the most natural and simple way: "For I see Christ in them... Many of them would act as led by the Spirit of God"19. Because of her open vision, occasionally she was maliciously, pejoratively, and restrictively characterized by some people, unable to understand her mission, as "ecumenical" and "non-conformist". Her attitude was generated by the experience of the "commandments of Christ as love, and not as struggle", as "she loved the Lord and she identified Him in any person and served Him in the suffering people encountered on the way" 20 . Two of her principles touch exactly this idea: "Never identify a person with the wrong way in which he is treating you, but see Christ in his heart"; and "If you do not like somebody, think that you see Christ in that person. Then, you would not even dare to say a word of criticism".

She was born in 1897, in a wealthy old family of Constantinople and, in the context of the tragic "population exchange", in 1923, she was forced to move to Thessaloniki. Although she had great career perspectives (being the second woman admitted to a Greek university), she chose, according to her inner call, to serve Christ and her neighbours: she left for England with only one pound in her pocket, to study chiropody and psychotherapy. There, in 1947, she opened a cabinet, where she treated poor people for free. After the end of World War II, she returned to Greece in Athens, where she opened a psychotherapy office. 1954 was the turning point period in her

\footnotetext{
${ }^{19}$ Maica Gavrilia - asceta iubirii, Editura Episcopiei Giurgiului, 2014, p. 7.

${ }^{20}$ Maica Siluana Vlad, Un model de admirat, in „Maica Gavrilia - asceta iubirii", p. 5.
} 
spiritual course, marked by the death of her mother. At that very moment she cut the last attachment that naturally connected her to earthly life: "Suddenly I died... for the world. The only path that was open in front of me now urged me to make the decisive step: go, sell your possessions, and give them to the poor; then come, follow me. But where? The call came totally unexpected: India... This was my destination" 21 .

She reached India, carrying nothing but her clothes and a Bible. Here she served the lepers and the poor in hospitals and ashrams. Meanwhile, although in direct contact with the Hindu gurus or Protestant and Catholic missionaries, she never ceased to be a faithful witness of her Orthodox faith, always replying: "Orthodoxy is my pride". After five years spent in India, in 1959 she entered the Monastery of the Holy Sisters Mary and Martha of Bethany. The canonic rule indicated by her spiritual father presupposed just reading the Gospels and the "Ladder" of St. John Climacus. Four years later, Mother Gavrilia received the schema from Father Amphilochius Makris in Patmos.

In the two decades to come, Mother Gavrilia alternated the contemplative life in the monastery with one year of missionary philanthropic service in East Africa, followed by three years back in India, with Archimandrite Lazarus Moore alongside, assisting him in translating the Psalter and some Church Fathers in the vernacular language, in Uttar Prades. Father Sophronius of Essex asked her, during this period, to becomethe abbess of his monastery of nuns, but she did not accept.

She spent her last thirteen years of life in her native Greece, first in a small apartment in the middle of Athens (half of day in prayer, and the rest of the time receiving crowds of people and assisting them in their illness), then for more than a year in the Monastery of Saint Nektarios of Aegina, and the last two years of ascetic life in a hermitage on the island of Leros. She received in

${ }^{21}$ Maica Gavrilia-asceta iubirii, p. 50. 
1991 the Great Schema from Father Dionysius of St. Anne Athonite Monastery. She passed away the following year, on the $28^{\text {th }}$ March.

If we were to identify the major virtues that animated Mother Gavrilia's spiritual life, we could summarize them in three directions. Starting from the definition of God as love, according to John the Evangelist, Mother Gavrilia's spiritual itinerary was a hymn of the divine love and sacrifice, "a holocaust" of the divine love. Among the many manuscripts found by those who dealt with her biography, there is a poem that seems to describe an itinerary of initiation in the asceticism of love, followed with confidence and consistency, regardless of the geography or the religious configuration:

Thou hast revealed me to the friends I did not know / Thou hast housed me in homes that did not belong to me / You have brought near what was far, and made from a stranger... a brother / Wherever you will lead me, / You the same art, / The only companion of my endless life, / Who bind forever my heart / With chains of all my joy that is unknown. / When man knows you, nobody is alien to him/ And no door is closed / $\mathrm{O}$, hear my prayer to never lose / The happiness of touching one while embracing the many ${ }^{22}$.

Her theological fundament is clearly expressed using again the symbol of the cross. There is only one single love expressed in two directions, as revealed by the two arms of the cross: vertical - the love of God, and horizontal - the love of the neighbor. While developing this fundamental ascetical idea, she also reveals a possible perspective regarding the rapport between mystical life and social service, here contextualized in the monastic world. To the vertical arm she associates, next to the love towards God, the prayer, the silence and solitude, while to the horizontal arm, next to the love towards the others, she speaks

${ }^{22}$ Ibidem, p. 11. 
about all kinds and forms of philanthropic service. But meanwhile she establishes a hierarchy - firstly, one has to make the vertical part of the cross, that is to experience the solitude and the desert where God likes to reveal Himself. Here one finds the necessary resource for loving the neighbor. Because the power to love is not ours, but it is a divine gift. Otherwise, if one goes out to serve the others without a preliminary preparation, one becomes a social activist, but his service has no spiritual dimension ${ }^{23}$.

The love for the others finds its sources in Christ's cross. She argues: "The cross is the symbol of self-sacrifice for the others... Christ has shown us this in his life, his teaching, his crucifixion, and his Resurrection. This is why true love remains always on the cross, but, in the same time, it is joyful in the light of resurrection" 24 .

Love and compassion is also well present in the model of the Holy Virgin. As in mother Maria's social vision, the Mariological fundament constitutes the prolongation of Christ's kenosis in serving those in need. In the line of ancient tradition, for Mother Gavrilia, the Virgin Mary is the archetype of the perfect monastic. She identifies four characteristics that picture the Virgin's image: obedience (Luke 1: 38), humbleness and compassion (calumniated when bearing Christ in her womb without being married, she stands and supports those in need as one who knows well what suffering means), exile in Egypt (type for those marginalized by society), a mother who loses her child (an image for mothers who lose their children in wars or in other various situations), when her child was about to die, she was entrusted to the protection of John the Apostle (an image for the old people who need protection). On the one hand, she argues that "Virgin Mary's itinerary follows a normal course life of the human" and, on the other hand, in consequence, she manifests her

${ }^{23}$ Ibidem, pp. 467-468.

${ }^{24}$ Ibidem, p. 260. 
com-passion with different categories of people reflecting each of these stages ${ }^{25}$.

Beyond her erudition and linguistic talent, at the spiritual level, Mother Gavrilia knew very well the five "languages" of spiritual ecumenism: the smile, tears, touch, prayer, and love. "With these languages, one can travel around the world and the entire world is yours. I love all the same - regardless of religion or nationality, regardless doesn't matter what. God's people everywhere..."26. This is why she envisaged all people in her social service, regardless of their religion or nationality. When somebody asked her why she considers the Jewish or the Indians as her people, she used to describe them as "people who were waiting for Christ, although perhaps unaware of His presence, working under the protection of the Holy Spirit". Her missionary principle was circumscribed to the quality and quantity of love that one offers to all the others, without discrimination. For her, the most effective method of preaching the gospel was to love and be loved. She did not force anyone's way, but she let God reveal Himself to them, she just prayed.

Secondly, as already anticipated, next to love, and as its consequence, joy was an essential ingredient in all her work. In her vision, joy is a gift of the Lord that comes as a result of grace - "May my joy be in you" (John 15:11). The way to live it as a permanent event was related to prayer and compassion in unison with the others, accompanied by thanksgiving to God for all that occurs during earthly life. When the human being loves God, and does not judge anyone, but sees everyone as somebody waiting for Christ, one "gladly receives God's joy and offers it to others... and he begins to say thank you, thank you, thank you! And he dances for joy" 27 .

\footnotetext{
${ }^{25}$ Ibidem, p. 322.

${ }^{26}$ Ibidem, p. 290.

${ }^{27}$ Ibidem, pp. 345-346.
} 
By the same token, she openly and courageously emphasized that the love and humbleness of Christ expressed in the service of the brother become the very way to experience the resurrection (the eschatological dimension of social service): "Any place may become a place of Resurrection, if the Humility of Christ becomes the way of our life".

Her passage in this earthly world was discreet, but she left deep traces in the consciousness of many. Her memory is like an echo reverberating: "Love and follow Him!" Her precious testament invites us to an exercise of imitation: "When I leave this world, as the boat leaves no trace on the surface of the water as it passes, so I will not leave any trace... I have no conscience regrets... That is passionlessness. He leads me in my way, and I follow Him, looking at His miracles. I'm just a spectator". Consequently, "her life... is His call... her call... The choice is ours" 28 .

\section{Conclusion}

Finally, there are two aspects to be mentioned. Firstly, both Mother Maria and Mother Gavrilia's life obliterated the inane distinctions that one so often makes between inner life and service, between contemplation and social action. They did not theorise or theologise on the reality of the Church, society, Christian life, or something else. Their theological creed was to love with the love that proceeds from complete abandonment to Christ, and to act as that love dictates. At one time, this might be expressed in social action, at another time in secluded hesychia. The difference is immaterial, because the Source is the same.

Secondly, using the comparative method, I will evoke some spiritual constants identified in the itineraries of both monastics analysed above, that might give evidence of the missionary role of contemporary monasticism reflected in two case studies - one

${ }^{28}$ Ibidem, p. 624. 
from the Western world and the other one from the Eastern area, both representative of the Orthodox contemporary Church.

\begin{tabular}{|c|c|c|}
\hline $\begin{array}{l}\text { CONTEMP } \\
\text { LATIVE } \\
\text { LIFE AND } \\
\text { SOCIAL } \\
\text { SERVICE }\end{array}$ & $\begin{array}{l}\text { Mother MARIA } \\
\text { SKOBTSOVA }\end{array}$ & $\begin{array}{l}\text { Mother GAVRILIA } \\
\text { PAPAIANNIS }\end{array}$ \\
\hline $\begin{array}{l}\text { Monachos } \\
\text { "extra } \\
\text { muros" }\end{array}$ & $\begin{array}{l}\text { A new type of } \\
\text { community, "half } \\
\text { monastic and half } \\
\text { fraternal", which would } \\
\text { connect spiritual life } \\
\text { with service to those in } \\
\text { need, in the process of } \\
\text { showing "that a free } \\
\text { Church can perform } \\
\text { miracles". }\end{array}$ & $\begin{array}{l}\text { A new type of community: } \\
\text { a monastery in the world, } \\
\text { with opened doors to the } \\
\text { sorrow of the people in } \\
\text { need. }\end{array}$ \\
\hline $\begin{array}{l}\text { Principle of } \\
\text { life }\end{array}$ & $\begin{array}{l}\text { Only someone who is } \\
\text { in love has the right to } \\
\text { call oneself a human } \\
\text { being. }\end{array}$ & $\begin{array}{l}\text { Where you go, what you do, } \\
\text { how you work, or whether } \\
\text { you help somebody or not, } \\
\text { does not matter so much. } \\
\text { What really matters is the } \\
\text { quality and quantity of love } \\
\text { you offer to all, without any } \\
\text { discrimination. }\end{array}$ \\
\hline $\begin{array}{l}\text { Christ's self- } \\
\text { abasement - } \\
\text { a model for } \\
\text { our daily life: } \\
\text { the love of } \\
\text { God and } \\
\text { neighbour } \\
\text { form a single } \\
\text { truth }\end{array}$ & $\begin{array}{l}\text { Christ gave us two } \\
\text { commandments: to } \\
\text { love God, and to love } \\
\text { our fellow man. } \\
\text { Everything else, even } \\
\text { the commandments } \\
\text { contained in the } \\
\text { Beatitudes, is merely } \\
\text { an elaboration of these }\end{array}$ & $\begin{array}{l}\text { There is only one single } \\
\text { love, expressed in two } \\
\text { directions, as revealed by } \\
\text { the two arms of the cross: } \\
\text { the vertical - the love of } \\
\text { God, and the horizontal - } \\
\text { the love of the neighbor. } \\
\text { The vertical arm -love } \\
\text { towards God, prayer, }\end{array}$ \\
\hline
\end{tabular}




\begin{tabular}{|c|c|c|}
\hline & $\begin{array}{l}\text { two commandments } \\
\text { which contain within } \\
\text { themselves the totality } \\
\text { of Christ's Good News. } \\
\text { Furthermore, Christ's } \\
\text { earthly life is nothing } \\
\text { other than the } \\
\text { revelation of the } \\
\text { mystery of the love of } \\
\text { God and love of the } \\
\text { neighbour. }\end{array}$ & $\begin{array}{l}\text { silence and solitude; the } \\
\text { horizontal arm - love } \\
\text { towards the others, various } \\
\text { forms of philanthropy. }\end{array}$ \\
\hline $\begin{array}{l}\text { Our } \\
\text { neighbour is } \\
\text { a "christ" }\end{array}$ & $\begin{array}{l}\text { In our God-maternal } \\
\text { soul, not only is the } \\
\text { birth of the Son of God } \\
\text { announced and Christ } \\
\text { born, but there is also a } \\
\text { development of the } \\
\text { keen perception of } \\
\text { Christ's image in other } \\
\text { souls. }\end{array}$ & $\begin{array}{l}\text { Never identify a person } \\
\text { with the wrong way in } \\
\text { which he is treating you, but } \\
\text { see Christ in his heart. }\end{array}$ \\
\hline $\begin{array}{l}\text { The } \\
\text { ecumenical } \\
\text { dimension of } \\
\text { Philanthropy }\end{array}$ & $\begin{array}{l}\text { "She helps everyone. } \\
\text { For a Christian like her, } \\
\text { it is neither Jewish nor } \\
\text { Greek. If you were in } \\
\text { danger, she would have } \\
\text { helped you too". Her } \\
\text { social service is } \\
\text { generated by an inner } \\
\text { mystical perspective of } \\
\text { a kenotic type, as } \\
\text { professed by Jesus } \\
\text { Himself. }\end{array}$ & $\begin{array}{l}\text { With these languages } \\
\text { (smile, tears, touch, prayer, } \\
\text { and love) you can travel } \\
\text { around the world and the } \\
\text { entire world is yours. I love } \\
\text { all the same - regardless of } \\
\text { religion or nationality, } \\
\text { regardless doesn't matter } \\
\text { what. God's people } \\
\text { everywhere ... the most } \\
\text { effective method of } \\
\text { preaching the gospel is to } \\
\text { love and be loved. }\end{array}$ \\
\hline $\begin{array}{l}\text { The } \\
\text { eschatologica }\end{array}$ & $\begin{array}{l}\text { The way to God lies } \\
\text { through love of people. }\end{array}$ & $\begin{array}{l}\text { When one loves God and } \\
\text { does not judge anyone, but }\end{array}$ \\
\hline
\end{tabular}




\begin{tabular}{|l|l|l|}
\hline $\begin{array}{l}\text { I fundament } \\
\text { for social } \\
\text { service }\end{array}$ & $\begin{array}{l}\text { At the Last Judgment I } \\
\text { shall not be asked } \\
\text { whether I was } \\
\text { successful in my } \\
\text { ascetic exercises, nor } \\
\text { how many bows and } \\
\text { prostrations I made. } \\
\text { Instead, I shall be } \\
\text { asked: Did I feed the } \\
\text { hungry, clothe the } \\
\text { naked, visit the sick } \\
\text { and the prisoners? That } \\
\text { is all I shall be asked. }\end{array}$ & $\begin{array}{l}\text { sees everyone as somebody } \\
\text { waiting for Christ, one } \\
\text { gladly receives God's joy, } \\
\text { and offers it to others... and } \\
\text { one begins to say thank } \\
\text { you, and dances for joy... } \\
\text { Thus every place may } \\
\text { become a place of } \\
\text { Resurrection, if the humility } \\
\text { of Christ becomes the way } \\
\text { of our life. }\end{array}$ \\
\hline $\begin{array}{l}\text { The Holy } \\
\text { Fools - } \\
\text { saints of } \\
\text { freedom }\end{array}$ & $\begin{array}{l}\text { Freedom calls us to act } \\
\text { the Fool for Christ's } \\
\text { sake, at variance with } \\
\text { enemies, and even } \\
\text { friends, to develop the } \\
\text { life of the Church in } \\
\text { just that way in which } \\
\text { it is most difficult. And } \\
\text { we shall live as Fools, } \\
\text { since we know not only } \\
\text { the difficulty of this } \\
\text { way of life, but also the } \\
\text { exaltation of sensing } \\
\text { God's hand on our } \\
\text { work. }\end{array}$ & $\begin{array}{l}\text { Thecomes a love bomb } \\
\text { clearing millions of acres... } \\
\text { not only the desert, but half } \\
\text { the world. Do not get } \\
\text { attached to any place or } \\
\text { person, but only to Christ. } \\
\text { Go wherever the Holy Spirit } \\
\text { will lead you, bringing his } \\
\text { love to all, beyond } \\
\text { boundaries and } \\
\text { discriminations. Your } \\
\text { destination is to love. }\end{array}$ \\
& & \\
\hline
\end{tabular}

\section{Bibliografie}

1. Arjakovsky-Klépinine, Hélène, Bucuria dăruirii - o biografie spirituală, in "Iubirea nebună de aproapele. Viața și invățăturile Maicii Maria Skobțova", Sibiu, Deisis, 2008. 
2. Hackel, Sergei, Pearl of Great Price: the Life of Mother Maria Skobtsova, Crestwood, NY, St. Vladimir's Seminary Press, 1981.

3. Maica Gavrilia - asceta iubirii, Editura Episcopiei Giurgiului, 2014.

4. Maica SiluanaVlad, Un model de admirat, in „Maica Gavrilia - asceta iubirii".

5. Plekon, Michael, The Sacrament of the Brother/ Sister: The Lives and Thought of Mother Maria Skobtsova and Paul Evdokimov, in "Saint Vladimir Theological Quarterly", 49 (2005), 3, pp. 313- 334.

6. Skobtsova, Maria, On Imitating the Mother of God, in „Mother Maria Skobtsova: Essential Writings", Maryknoll NY, Orbis 2003.

7. Idem, The Mysticism of Human Communion, in "Mother Maria Skobtsova: Essential Writings”, Maryknoll NY, Orbis 2003.

8. Idem, The Second Gospel Commandment, in "Mother Maria Skobtsova: Essential Writings", Maryknoll NY, Orbis 2003.

9. Idem, Types of Religious Lives, in "Mother Maria Skobtsova: Essential Writings", Maryknoll NY, Orbis 2003.

10. Idem, Under the signs of our times, in "Mother Maria Skobtsova: Essential Writings”, Maryknoll NY, Orbis 2003. 